\title{
EXPLORING SUBJECTS SWAPPING, AVAILABILITY AND PUPILS' PARTICIPATION OF PHYSICAL EDUCATION AMONG PRIMARY SCHOOLS IN BAKU, AZERBAIJAN
}

\author{
Oluwaseyi Olubunmi, Sodiya ${ }^{1 \mathrm{i}}$, \\ Gunay Imanguliyeva ${ }^{2}$ \\ ${ }^{1} \mathrm{PhD}$, Organization and Planning of Education, \\ Khazar University, Neftchiler Campus, \\ 41 Mehseti Street, Baku, AZ1096, \\ Azerbaijan \\ Master's in Educational Management, \\ School of Education, \\ Azerbaijan Diplomatic Academy University, \\ Azerbaijan \\ ${ }^{2}$ Master in Educational Management, \\ School of Education, \\ Azerbaijan Diplomatic Academy University, \\ Ahmadbey Aghaoglu str. 61 Baku, 1008, \\ Azerbaijan
}

\begin{abstract}
:
The study investigates the relationship between subject swapping, availability, and pupil participation in the physical education lesson. A quantitative survey was undertaken, and amongst 512 survey respondents, a random selection of 140 pupils was chosen. Pearson correlation was performed after descriptive statistics was used to analyze the relative frequency on the proportion of time a value occurred. The findings indicate a strong, positive relationship amongst the three variables. The response of the pupils for all parameters suggested that the school switched physical education frequently. Pupils should be given opportunity and access to physical activity on a regular basis in order to develop physically and mentally.
\end{abstract}

Keywords: children, obesity, physical activity, physical education, participation

\section{Introduction}

Physical education is an educational subject related to the maintenance of the human body through exercise and the development of knowledge about our body. The

${ }^{i}$ Correspondence: email osodiya6092@ada.edu.az 
International Council of Sport Science and Physical Education (ICSSPE), International Association of Physical Education and Sport for Girls and Women (IAPESGW), International Association for Physical Education in Higher Education (AIESEP) discussed the importance of physical education as the only sure chance for all schoolchildren to have access to health-enhancing exercise that enables them to lead healthy lives. The goal of physical education is to develop physically educated people who have the knowledge, skills, and confidence to enjoy healthy physical activity. Students learn the necessary skills that will enable them to participate in various physical activities throughout their lifestyle (Cheatom et al., 2014). As stated in the concept of general education of the national curriculum of Azerbaijan, for the purpose of education it is envisaged to move to children's sensitivity, aesthetic and artistic taste, moral and spiritual qualities, physical training and self-service skills (Cabinet of Ministers of the Azerbaijan Republic, 2006).

The national physical education curriculum in Azerbaijan on high-quality physical education programs aligns with the international standard. The International Standards for Physical Education and Sport for School Children (ICHPER.SD) in collaboration with United Nations Educational, Scientific, and Cultural Organization (UNESCO) stated at a meeting in 2001 that global standards are universal, which is what every child/adolescent should know and be able to do as a result of the curriculum. He went on to say that it cannot be assumed that every child/adolescent in each country/country will be able to meet all standards of content at any given time. Nevertheless, in the spirit of the right of every child/adolescent to physical education, the profession in the country/nation concerned must make an ongoing contribution to the achievement of standards. The Azerbaijan curriculum (2.1.1.) for primary education, general education standards, which provide justification for the passing of the subject by a certified physical education teacher who has a full understanding of physical fitness as an important factor in promoting health and protection, able to provide training and training to improve the ability of pupils to move, as well as using appropriate tools and training as a means of teaching students in various fields of sports, mastering the rules of personal hygiene and methods of strengthening the body using natural means, transferring the original anatomical concept of the body structure, as well as the discipline of the body.

The purpose of this study is to explore the level of physical education to ensure whether the school has physical education for pupils' participation and to whether schools provide physical education for pupils' participation and swapping of physical education lessons in Baku elementary schools. We also looked at the relationship between the pupils' responses to physical education in school daily and pupils' participation in physical education. Today, students continue to experience low access to physical education. There is no doubt that physical activity has a positive health benefit, such as improved emotions and body weight control. More than $80 \%$ of the world's adolescents are under-active, and Member States of the World Health Organization have agreed to reduce physical underactivity by $10 \%$ by 2025 (WHO, 2018). However, physical activity of more than 60 minutes a day will provide additional health benefits, including activities 
that strengthen muscles and bones at least three times a week. Physical education is a part of the overall educational process and is required in elementary schools throughout the world (Pate et al., 1995; European Commission for Youth and Sport, 2012) Australia (Commonwealth of Australia, Department of Health and Aging, 2012), in New Zealand (New Zealand Ministry of Health, Physical Activity Guidelines, 2010) almost all primary school children are required to participate in some form of physical education. Today, pupils continue to experience reduced time for break and physical education (PE) classes throughout the school day (Dills, Morgan, \& Rotthoff, 2011). However, many studies have shown that a student's participation in physical activity during and after school physical activity increases in academic achievement (Centers for Disease Control and Prevention, 2010) classes on physical activity have a positive effect on academic performance (Harvey et al., 2018), improving academic achievement and reducing obesity (Donnelly et al., 2013).

Considering Azerbaijan as one of the WHO member the road map to reducing inadequate physical activity levels among primary school pupils is to ensure that students is to ensure that physical education classes are held, As stated in the national curriculum of Azerbaijan, by evidence of physical education programs characterized by the training of certified physical education teachers with the availability of facilities and equipment such as a playground, a field, an open space for free space to encourage students to participate in physical education and physical activity in the school.

\section{Research Question}

To explore the availability of physical education classes, pupil participation and swapping of physical education classes among public primary schools in Baku, Azerbaijan. This inquiry was guided by the following research questions listed below:

1) How often do schools have physical education lessons? (Availability of Physical Education at School)

2) How often do school swap physical education lessons for other school subjects? (Changing PE Lesson for another subject )

3) How often do pupils participate in physical education lessons at school? (Pupils Daily Participation)

4) What is the relationship between availability, swapping of physical education lessons for other subjects and pupils' participation?

\section{Literature Review}

The engagement theory of teaching and learning in education was used to guide the research variables during the data gathering procedure in this study, it's an approach for technology-based teaching and learning (Kearsley \& Schneiderman, 2006). The primary objective of the engagement theory is for students to be able to engage in meaningful learning activities by collaborating and attempting the teacher's assigned tasks. This type 
of approach will motivate students both internally and externally to participate in activity That being said, one of the barriers to pupil participation in physical education has been identified in several studies as a gap between theory and practice, such as school policy in providing improved quality physical education measures to enhance pupil participation and physical activity level, as well as other potential factors throughout many studies (Korthagen, 2017; Lunenberg \& Korthagen, 2009; Pakhalchuk \& Holyuk, 2018; Hills, 2007). One of the first stages in achieving effective school-based physical education programs in our various primary schools might be closing the gap between theory and practice.

The study of Mackenzie, Son, \& Eitel (2018) their study was relevant and meaningful because it increased participants' intrinsic willingness to engaged in both physical exercise and science education; this study is an example of bringing engagement theory into reality of teaching school-based physical education. Below is a structural model for the relationship between the availability of physical education lessons and pupils' participation in physical education lessons daily in Baku public primary schools?

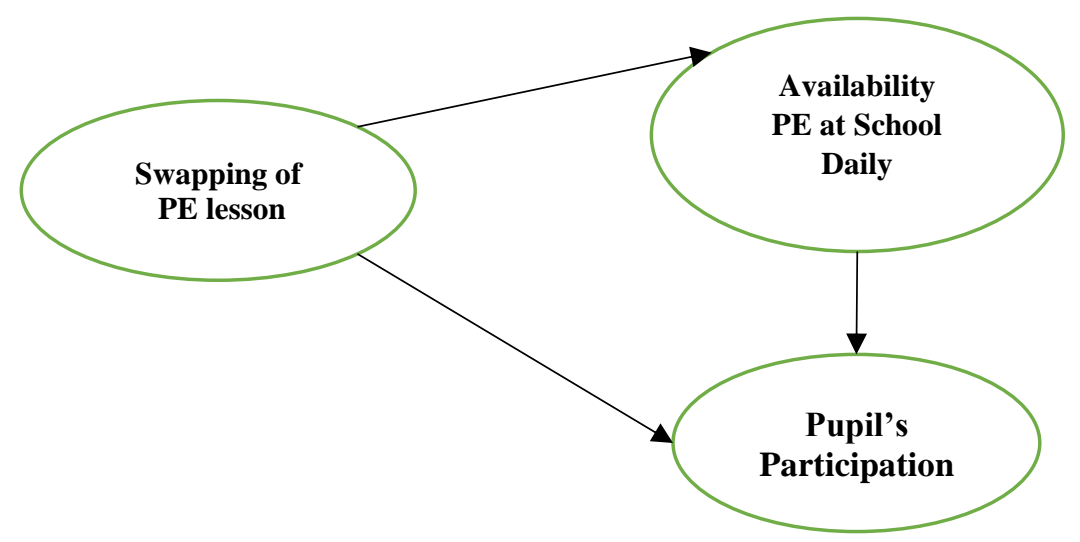

Figure 1: Conceptual Model: Lesson Swapping Physical Education Availability and Pupil's Participation

Figure 1, conceptual model physical education availability and pupil participation, shows that students rely on the school to provide a high-quality, well-structured, and comprehensive physical education activity. According to Jenkinson \& Benson (2010), study barriers to providing physical education and physical activity in Victorian State Secondary Schools published in the Australian Journal of Teacher Education that policy and implementation are widespread and interests compete for timetable and curriculum space Physical education is simply stated on the timetable in most elementary schools, but it is not delivered, and neither is the number of days for physical education lessons between twenty and twenty-five minutes, which has no influence on the pupils' level of physical activity. Physical education is a required topic in all Hong Kong schools. It is recommended that schools set aside $5 \%$ to $8 \%$ of overall curricular time. In practice, this translates to 60 to $90 \mathrm{~min}$ of PE time per week in secondary schools (Ha, Lonsdale, Lubans, \& Ng, 2017). 


\subsection{Pupils Experiences of Physical Education}

It is critical to remember that in physical education, students acquire a range of strategies, methods, and concepts for achieving and completing difficult tasks as well as developing motor abilities. By doing a basic or difficult activity, they think about what they are doing, analyses the situation, and make decisions. Students' physical activity literacy, motivation, and enjoyment of physical education and physical activity level were measured in a randomized study on teachers' physical literacy, self-efficacy, and students' learning outcomes. Teachers' physical literacy and self-efficacy, however, were associated with effective physical education teaching that fluent students' physical literacy and exercise habits. Teacher's self-efficacy was associated with effective physical education teaching that fluence students' physical literacy and physical activity participation. However, despite most of the students reported that they enjoy the physical education class and physical activity some of the students still stated that they dislike it because it is not fun (Behzadnia, Adachi, Deci, and Mohammadzadeh, 2018). As cited in (Syrmpas, Digelidis, Watt, and Vicars, 2017), a study conducted in Greece, attaining the goals of the Greek physical education curriculum reforms required that the delivery of the lesson should be in multidimensional environments through the introduction of different teaching methods. On the other hand, the stakeholders have acknowledged how educators' teaching preferences and quality have influences on students' learning. Bechter, Dimmock, and Jackson (2019) pupils in the intervention group displayed a more positive change in autonomous motivation for physical education, as well as in autonomy and relatedness need satisfaction, effort, and physical education learning-efficacy due to the teaching style of student's Centre strategy. Physical education is a part of the overall educational process and is required in elementary schools throughout the world (Constantinides, Montalvo, \& Silverman, 2013; Constantinides et al., 2013; Anderson, Wynter, Grant, reports, \& 2017) and all elementary school children are required to participate in some form of physical education.

\subsection{Pupils Participation in Physical Education}

Several studies have indicated that pupil's participation in physical education is especially important because it has been proven to provide a range of significant advantages for pupils' health and wellbeing. When pupils feel comfortable, in charge, and encouraged by everyone, they enjoy participating in physical activity (Lewis, 2014a), this statement was supported by the study conducted on mental imagery and demonstration intervention on primary four pupil's acquisition of soccer dribbling skills stated that school physical education plays an important role in pupils' physical activity lives and that educators play an important role in children's physical activity interactions (Sodiya \& Syed Kamaruzaman, 2017). A series of recent studies have also indicated that apart from physical education health benefits, increasing physical exercise has significant academic benefits through enhancing pupils' cognition, concentration, and memory (Packham \& Street, 2019). In another study, the benefit of pupils participation in physical activity for mental health and well-being concluded that school-based physical education 
possesses certain positive qualities as well as considerations (Smedegaard, Christiansen, Lund-Cramer, Bredahl, \& Skovgaard, 2016) some key questions and notions are still not discussed in the literature, however, several barriers are preventing the participation of pupils in physical education at school which makes it difficult for pupils to gain from the significant benefit of physical education.

\subsection{Daily Physical Education Lesson at School}

Physical exercise may be integrated into the school daily activities in several forms, forty minutes or more of physical activity during scheduled physical education lessons would be considered as the daily physical activity requirement according to the world health organisation recommendation of moderate-intensity aerobic physical activity because physical activity is only one component of a comprehensive health and physical education program, there will be days when a health and physical education program will be ineffective (Ministry of Education, 2005). It is crucial to continue providing children with a range of experiences and opportunities to be involved during the day. According to studies, children have higher levels of physical exercise attendance as they are motivated and given the ability to explore new forms of physical activity. By having more options, children are more likely to find things that they enjoy because, children tend to find activities they like if they have more opportunities (European Union Erasmus Program, 2014). Pupils 'experiences in school-based physical education, physical activity participation, academic performance, and wellbeing, pupil's motivation in physical education. What emerged from the evaluation of the literature review indicates the importance of daily availability of physical education lesson related to pupil's health and wellbeing. The review further identifies a pattern in reducing the time of physical education lessons, which leads to a lower effect of school-based PE on increasing the pupils' level of physical activity.

\section{Methods and Materials}

\subsection{Descriptive Methodology}

This researcher utilized a quantitative descriptive approach to analyze the swapping, and availability of physical education (PE) in Baku primary schools and pupil participation. This procedure allows us to calculate and evaluate the responses of the participants using the population-based survey questionnaire for participants selection.

\subsection{Sample}

The research used a simple random sample, providing each member of the subset fair opportunities as part of the sampling procedure. The population of this study is the general elementary school in Baku approximately 307, with 395,773 pupils. The survey responses received from the participants were 512 pupils' who participated in the survey. However, based on selection criteria such as pupils' grades and age. The research study focuses on $3 \mathrm{rd}$ and 4 th graders both male and female aged between 8-10 years old. These 
grades stages are very important stages for the pupils in education because it is the stages when the pupil's transition from a lower grade to the upper grades. The total numbers of 70 male and 70 female, 140 pupils survey responses were randomly selected for this study.

Table 1: Participant's selection and sample

\begin{tabular}{|c|c|c|c|c|}
\hline $\begin{array}{c}\text { Estimated } \\
\text { Number of Public } \\
\text { Schools }\end{array}$ & $\begin{array}{c}\text { Estimated } \\
\text { Number of } \\
\text { Students }\end{array}$ & $\begin{array}{c}\text { Total } \\
\text { Participants } \\
\text { Size }\end{array}$ & $\begin{array}{c}\text { Sample } \\
\text { by Gender, Age } \\
\text { and Grade }\end{array}$ & $\begin{array}{c}\text { Total Participants } \\
\text { Selected Sample } \\
\text { Size }\end{array}$ \\
\hline 307 & 395773 & 512 & $\begin{array}{c}\text { Male/female, } \\
8-10 y r s,\end{array}$ & $\begin{array}{c}\text { Sample }(\mathrm{n}=70, \text { male } \\
/ \mathrm{n}=70, \text { female }) \\
\text { Pupils }=140\end{array}$ \\
\hline
\end{tabular}

The diagram below in Figure 2 shows the simple random sampling selection process.

Figure 2: Simple random sampling selection process

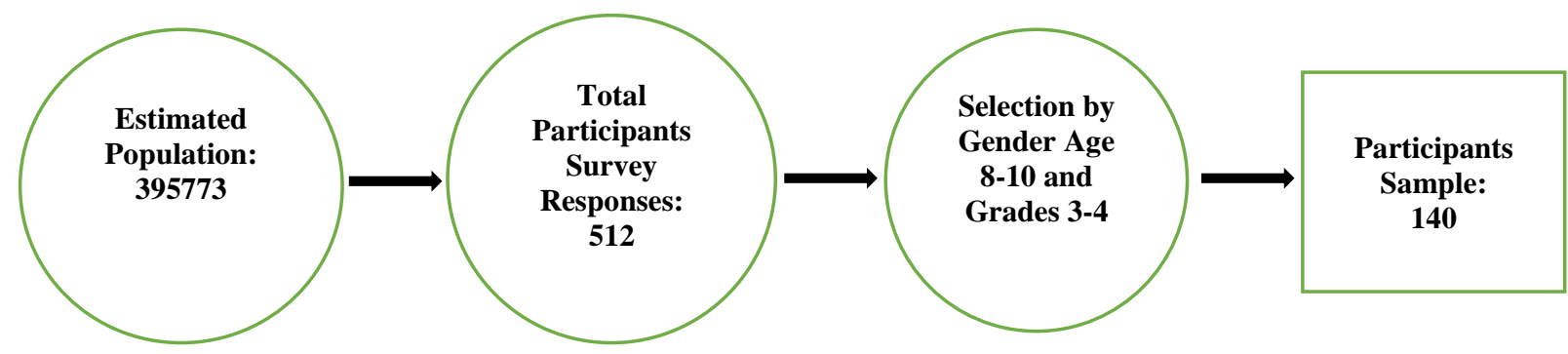

\subsection{Tools}

The survey was designed and evaluated by four academic staff at ADA university's department of education who are specialists in the area of social science research. It was tested for accuracy and consistency to ensure that it measures what it supposed to be measured. Following the content validity procedure, the survey was uploaded to $1 \mathrm{KA}$, a research tool portal that offers sophisticated assistance for all stages of the online survey process. 1KA user tools enable for the creation of an unlimited number of questionnaire items with complex question kinds and capabilities. Schoolteachers, parents, and coworkers were given the online questionnaire to share with their students. The instrument was used to gather data for a master's degree dissertation research study.

\subsection{Data Analysis}

This section of the study discusses how the data obtained from the participant's answer was analyzed using statistical data analysis. The data was analyzed for the descriptive analysis using IBM statistical analysis SPSS to give statistical details of the findings for the relationship between daily physical education classes at school and pupil participation in physical education lessons at school on a daily basis. 


\subsection{Analysis and Result}

We measure the central tendency of the data to report the data for the grade, gender, physical education lesson and pupil's participation in physical education lesson, variables. The distribution of pupils by age by gender, the average numbers of female pupils $(\mathrm{N}=70) 11.43 \%$ of the female are $3^{\text {rd }}$ grader and $38.57 \%$ are $4^{\text {th }}$ grader. While male pupils were $(\mathrm{N}=70) 8.57 \%$ were $3^{\text {rd }}$ grader and $41.43 \%$ were $4^{\text {th }}$ grader. The following results are shown in the (Table 2 and Figure 3) below.

Table 2: Frequency Table for Pupils' Gender by Age and Grade

\begin{tabular}{|c|c|c|c|}
\hline & Frequency & Percent (\%) & Valid Percent (\%) \\
\hline \multicolumn{4}{|l|}{ Gender } \\
\hline Male & 70 & 50 & 50 \\
\hline Female & 70 & 50 & 50 \\
\hline Total & 140 & 100.0 & 100.0 \\
\hline \multicolumn{4}{|l|}{ Age } \\
\hline 8 Years Old & 31 & 22.1 & 22.1 \\
\hline 9 Years Old & 43 & 30.7 & 30.7 \\
\hline 10 Years Old & 66 & 47.1 & 47.1 \\
\hline Total & 140 & 100.0 & 100.0 \\
\hline \multicolumn{4}{|l|}{ Grade } \\
\hline Grade 3 & 28 & 20.0 & 20.0 \\
\hline Grade 4 & 112 & 80.0 & 80.0 \\
\hline Total & 140 & 100.0 & 100.0 \\
\hline
\end{tabular}

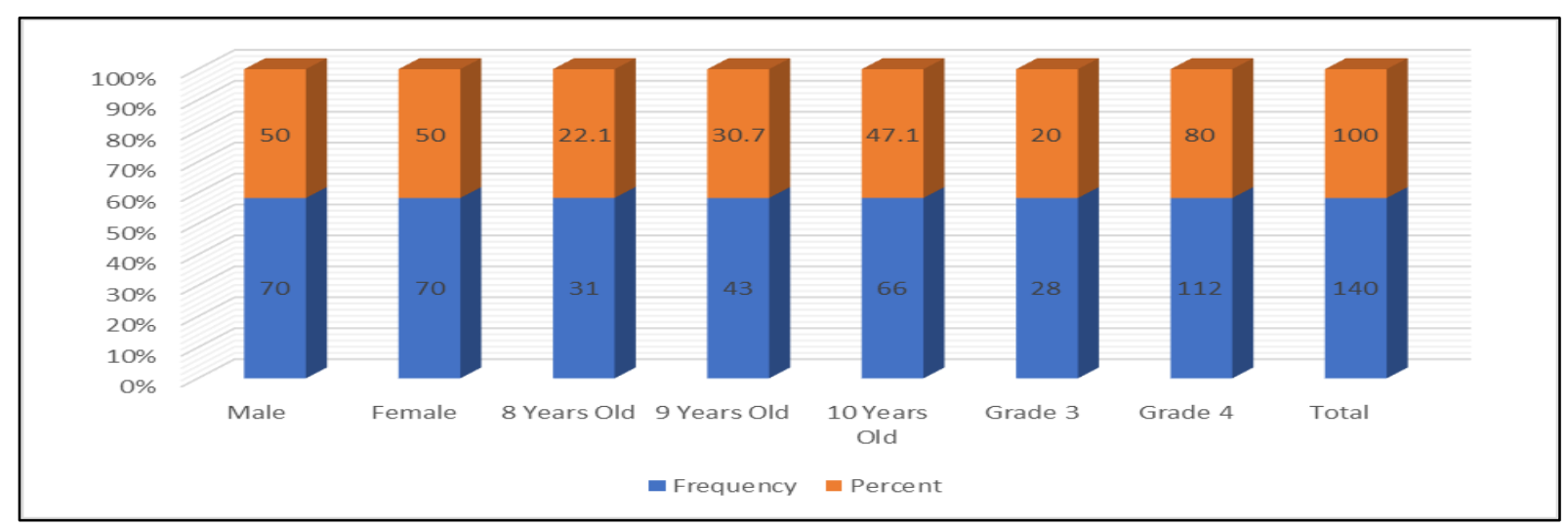

Figure 3: Pupils Gender by Age and Grade

We measure the central tendency of the data to report the data set for the Availability of physical education lessons, pupils' participation and swapping of physical education lesson. The frequency and percentage responses of pupil's based on the questionnaire item. The mean age of the participants was 9.24 years with a standard deviation of .774 and the mean grade 1.807 with a standard deviation of .3960. Among the participants the swapping of physical education lesson $(\mathrm{M}=1.9143, \mathrm{SD}=.61732)$ and the for the availability of physical education lesson $(\mathrm{M}=2.0929$, SD $=.49307)$, while the pupil's participation in physical education lesson was $(\mathrm{M}=2.2000, \mathrm{SD}=.63699)$ as seen in the Table 2 below. 
Table 3: Statistics for Mean and Standard Deviation

\begin{tabular}{|c|c|c|c|c|c|c|}
\hline & $\begin{array}{c}\text { Swapping } \\
\text { of Physical } \\
\text { Education Lesson }\end{array}$ & $\begin{array}{c}\text { Availability of } \\
\text { School Physical } \\
\text { Education Lesson }\end{array}$ & $\begin{array}{c}\text { Pupils Participation } \\
\text { in Physical } \\
\text { Education Lesson }\end{array}$ & $\begin{array}{c}\text { Pupils' } \\
\text { Age }\end{array}$ & $\begin{array}{l}\text { Pupils' } \\
\text { Grade }\end{array}$ \\
\hline \multirow[t]{2}{*}{$\mathbf{N}$} & Valid & 140 & 140 & 140 & 140 & 140 \\
\hline & Missing & 0 & 0 & 0 & 0 & 0 \\
\hline \multicolumn{2}{|c|}{ Mean } & 1.9143 & 2.0929 & 2.2000 & 9.24 & 1.807 \\
\hline \multicolumn{2}{|c|}{ Std. Deviation } & .61732 & .49307 & .63699 & .774 & .3960 \\
\hline
\end{tabular}

Research Question 1: How often do school have physical education lesson? (Availability of Physical Education at School)

Do you have physical education lessons at your school? (Never 7.9\%, Sometimes 75\%, Everyday $17.1 \%$ ).

Research Question 2: How often do school swap physical education lessons for other school subjects? (Changing PE Lesson for another subject)

Sometimes schools swap physical education lessons with another subject (Never 23\%, Sometimes 61\%, Everyday 15\%)

Research Question 3: How often do pupils participate in physical education lessons at school? (Pupils Daily Participation)

Do you participate in physical education lesson at school? (Never 17\%, Sometimes 63\%, Everyday $24 \%$ ).

Base on the result of the analysis we can state that the school provides physical education lessons for the pupils daily, the following results are shown in the table and figures below.

Table 4: Descriptive Analysis Availability of School Physical Education and Pupil's Participation

\begin{tabular}{|l|l|c|c|}
\hline Variables & Male & $\mathbf{N}$ & Marginal Percentage \\
\hline \multirow{2}{*}{ Gender } & Female & 70 & $50.0 \%$ \\
\hline \multirow{2}{*}{$\begin{array}{l}\text { Swapping of Physical } \\
\text { Education Lesson }\end{array}$} & Never & 70 & $50.0 \%$ \\
\cline { 2 - 4 } & Sometimes & 33 & $23.6 \%$ \\
\cline { 2 - 4 } & Every day & 21 & $61.4 \%$ \\
\hline \multirow{2}{*}{$\begin{array}{l}\text { Physical Education } \\
\text { Participation }\end{array}$} & Never & 17 & $15.0 \%$ \\
\cline { 2 - 4 } & Sometimes & 89 & $12.1 \%$ \\
\cline { 2 - 4 } & Every day & 34 & $63.6 \%$ \\
\hline \multirow{2}{*}{$\begin{array}{l}\text { Availability of Physical } \\
\text { Education Lesson }\end{array}$} & Never & 11 & $24.3 \%$ \\
\cline { 2 - 4 } & Sometimes & 105 & $7.9 \%$ \\
\cline { 2 - 4 } & Every day & 24 & $75.0 \%$ \\
\hline Valid & & 140 & $17.1 \%$ \\
\hline Missing & & 140 & $100.0 \%$ \\
\hline Total & & & \\
\hline
\end{tabular}


Figure 4: Descriptive Analysis Availability of

School Physical Education and Pupil's Participation

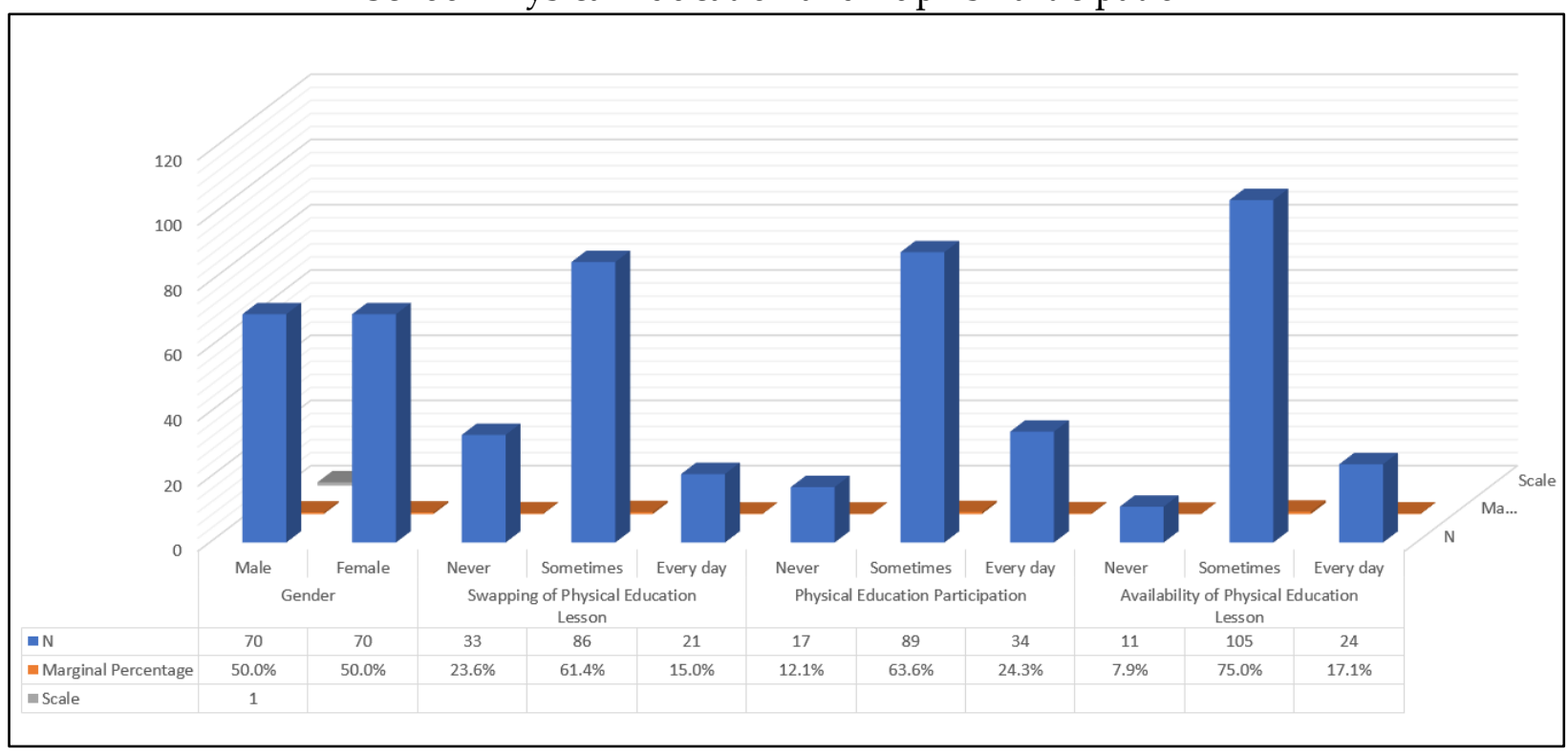

Research Question 4: What is the relationship between availability, swapping of physical education lesson for other subjects and pupils' participation?

The null hypothesis formulated for this research question states that:

Ho: There is no relationship between the pupil's survey responses on availability of physical education lesson, swapping of physical education lesson for other subjects and pupils' participation.

To answer the hypothesis, a Pearson correlation coefficient was computed to assess the relationship between the swapping of physical education lesson, the Availability of physical education lessons and pupils' participation in physical education lessons. There was a positive correlation between the three variables, $r=.650, n=140, p$ $=.001$. The correlation is significant at the 0.01 level (2-tailed). Physical Education Participation and Swapping of Physical Education Lesson appear highly correlated and Availability of Physical Education Lesson and Swapping of Physical Education Lesson also appear highly correlated as see in the table below. We rejected the null hypothesis, there is a correlation between swapping of physical education lesson, Availability of physical education lessons and pupils' participation in physical education lessons.

Table 5: Pearson correlation

\begin{tabular}{|l|l|c|c|c|}
\hline \multicolumn{2}{|c|}{} & $\begin{array}{c}\text { Availability } \\
\text { of Physical } \\
\text { Education } \\
\text { Lesson }\end{array}$ & $\begin{array}{c}\text { Physical } \\
\text { Education } \\
\text { Participation }\end{array}$ & $\begin{array}{c}\text { Swapping of } \\
\text { Physical } \\
\text { Education } \\
\text { Lesson }\end{array}$ \\
\hline $\begin{array}{l}\text { Availability of } \\
\text { Physical Education } \\
\text { Lesson }\end{array}$ & Pearson Correlation & 1 & $.650^{* * *}$ & .042 \\
\cline { 2 - 5 } & Sig. (2-tailed) & & .000 & .623 \\
\cline { 2 - 5 } $\begin{array}{l}\text { Physical Education } \\
\text { Participation }\end{array}$ & $\mathrm{N}$ & 140 & 140 & 140 \\
\cline { 2 - 5 } & Pearson Correlation & $.650^{* *}$ & 1 & .079 \\
\cline { 2 - 5 } & Sig. (2-tailed) & .000 & & .355 \\
\hline
\end{tabular}


Oluwaseyi Olubunmi, Sodiya; Gunay Imanguliyeva

EXPLORING SUBJECTS SWAPPING, AVAILABILITY AND PUPILS' PARTICIPATION

OF PHYSICAL EDUCATION AMONG PRIMARY SCHOOLS IN BAKU, AZERBAIJAN

\begin{tabular}{|l|l|c|c|c|}
\hline \hline & $\mathrm{N}$ & 140 & 140 & 140 \\
\hline \multirow{2}{*}{$\begin{array}{l}\text { Swapping of Physical } \\
\text { Education Lesson }\end{array}$} & Pearson Correlation & .042 & .079 & 1 \\
\cline { 2 - 5 } & Sig. (2-tailed) & .623 & .355 & 140 \\
\cline { 2 - 5 } & $\mathrm{N}$ & 140 & 140 & \multicolumn{4}{|l}{} \\
\hline \multirow{2}{*}{$*$. Correlation is significant at the 0.01 level (2-tailed). }
\end{tabular}

Figure 5: Pearson correlation

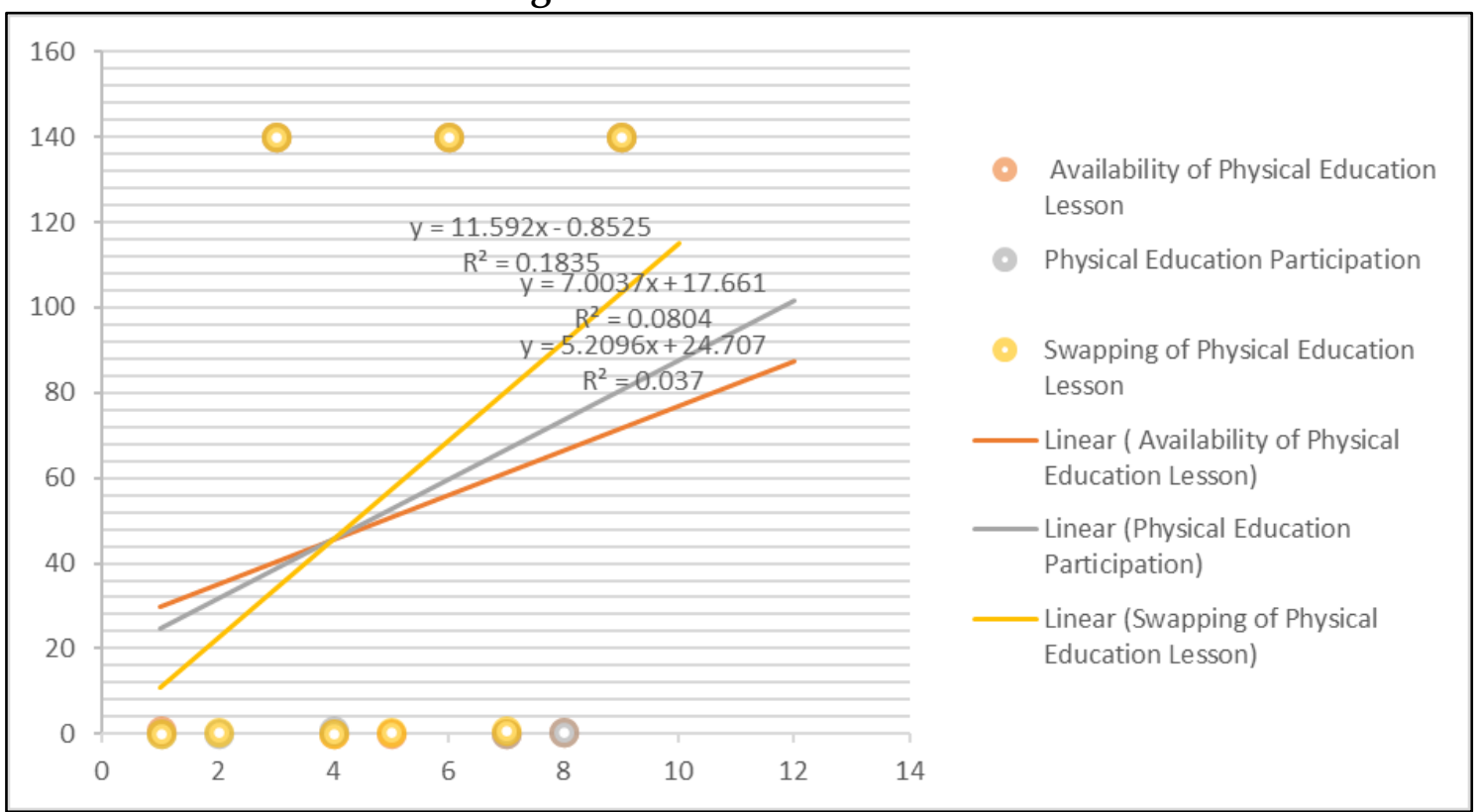

Figure 6: Correlation between Pupils

Participation and Availability of Physical Education

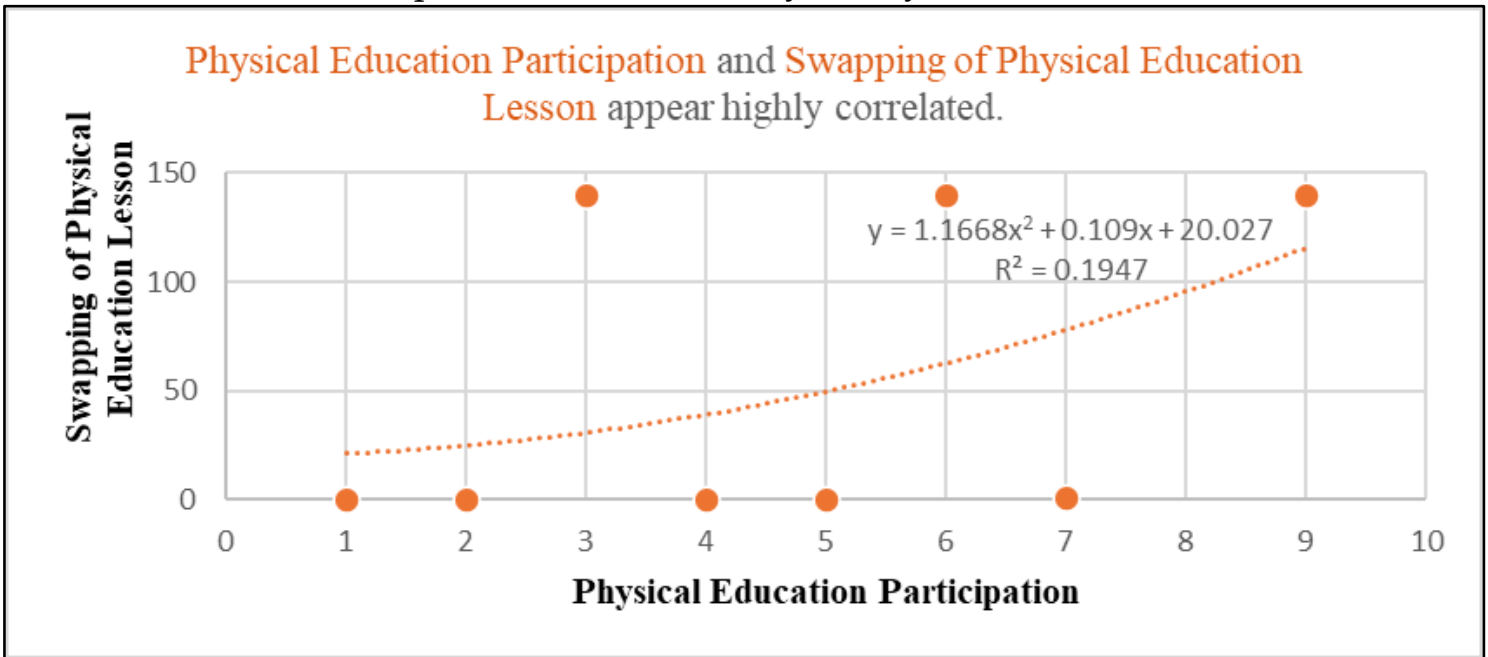


Figure 2: Correlation between Swapping of

Physical Education lesson and Pupils' Participation

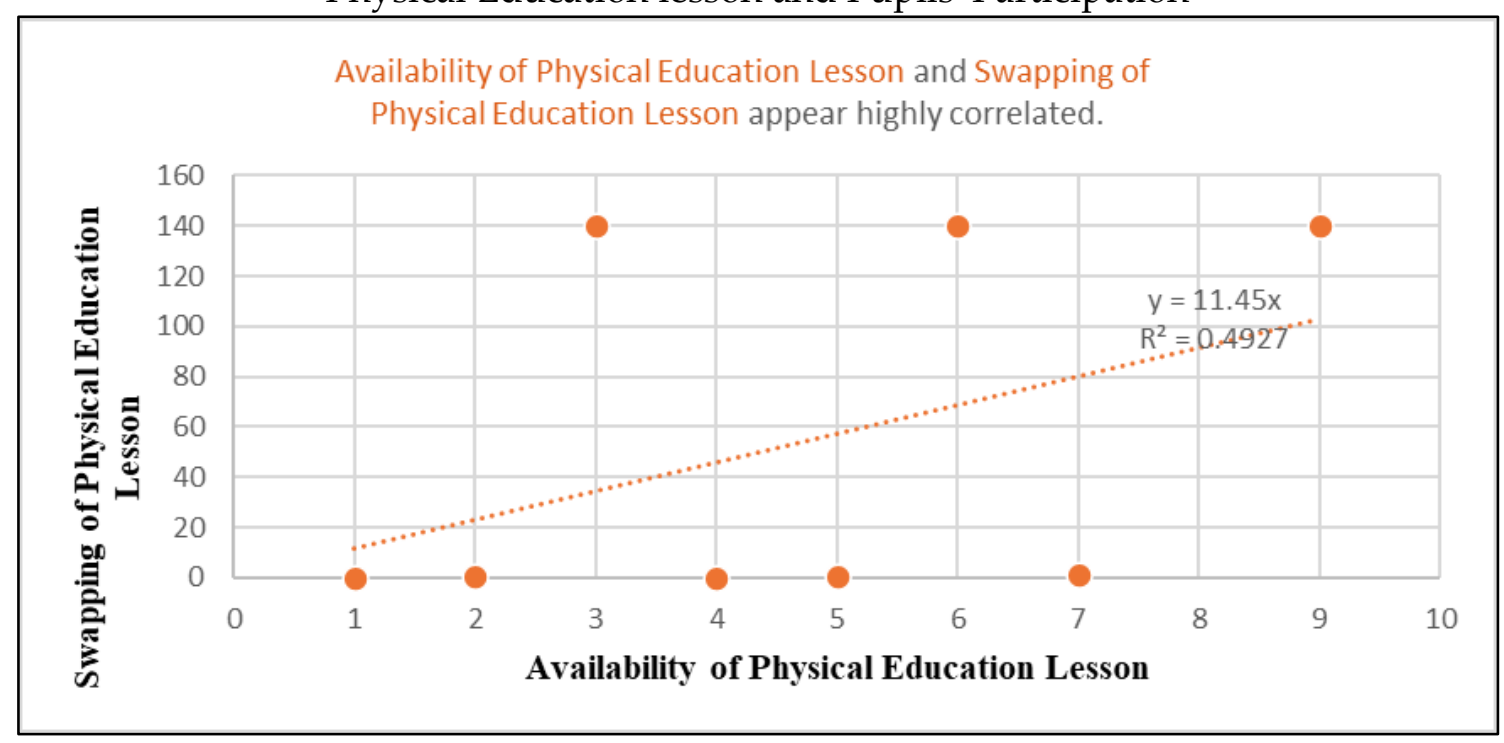

Figure 8: Correlation Between Swapping of Physical Education Lesson and Availability of Physical Education at School

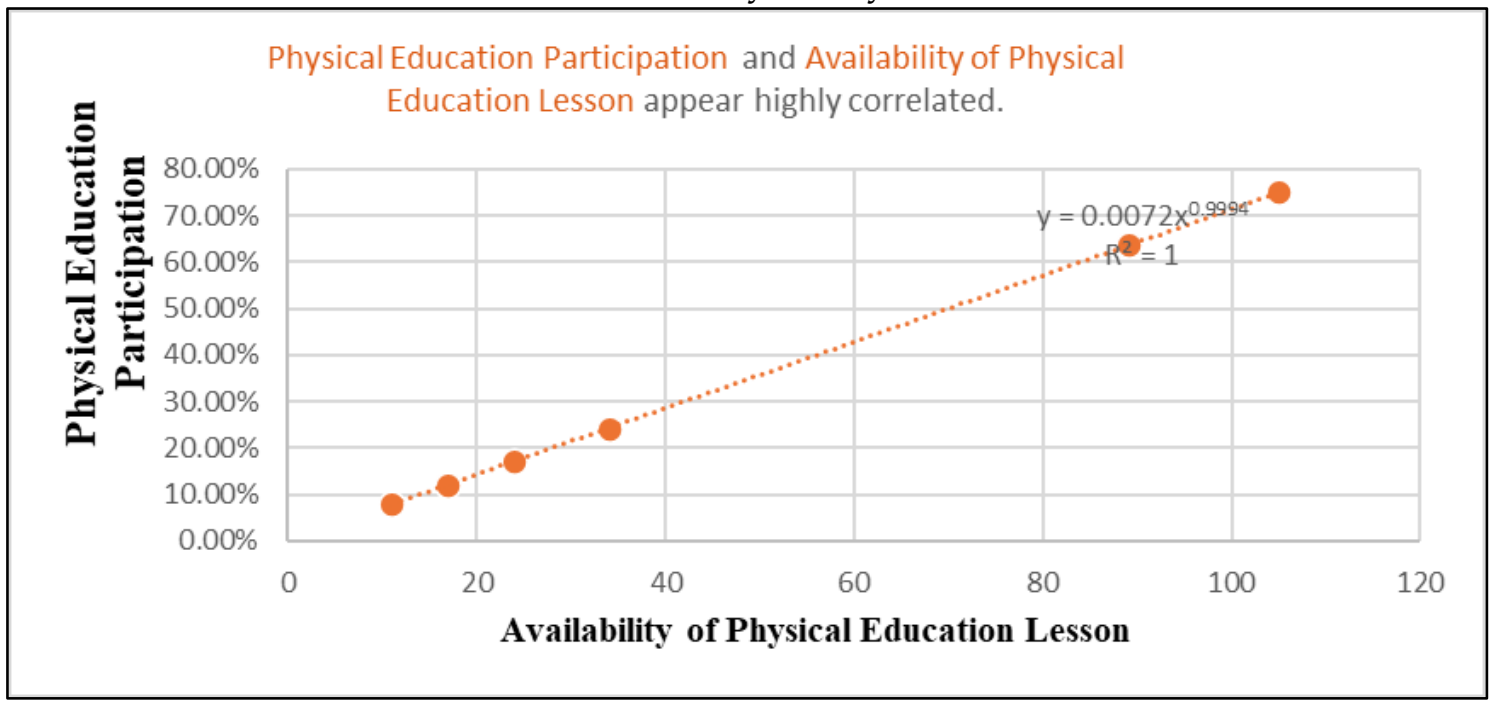

\section{Discussion}

Several researchers in the field of physical education have shown a close relationship between the availability of physical education as part of the problem affecting schoolbased physical education and its impact on pupils' interest in participating in physical education and physical activity (Haerens et al., 2011; Lewis, 2014; Prins et al., 2010; Rasberry et al., 2011). According to some researchers, physical education entails teaching wellbeing exercises and participating in high amounts of moderate to intense exercise during physical education classes (SHAPE, 2014; Quitério, 2013; Hills et al., 2015). Exercise and physical activity should start at an early stage in life to help the pupils develop healthy lifestyle habits that translate into reducing health risks in adulthood. The 
findings of this study show that if the school increases the numbers of physical education lesson and put a stop to swapping the subject lesson for another subject, the availability level will increase and the pupil's participation would also increase (see Pearson correlation table 5, figure 5, 6, $7 \& 8$ ). The right of every child to learn, achieve the standards and be physically educated to embrace physical education as a means to fulfil a fundamental human right. Physical education and school sports programs should be creative, include the whole school in regular or weekly exercise programs, and, most notably, be completely embedded into a cross-school goal of maximizing participation, increasing achievement, and transforming attitudes toward learning to affect whole school attendance (Stead \& Nevill, 2017). The literature of this present study also discovered that physical education, physical exercise, and sport have been found to have a positive effect on the degree to which pupils feel attached to their school; pupils' aspirations; the extent to which positive social behaviors occur within the school; and the growth of leadership and civic skills. The teachers want to implement physical education activities to the fullest but they are hindered by the insufficient time for lessons Stead \& Nevill, (2017) further stated that physical education time allocation has decreased in the majority of western schools over the past decade, although time allocation for other academic subjects has increased. Budget constraints and the need to achieve academic goals have forced schools to reduce physical activity in order to improve academic results. mentioned that pupils' participation in physical activity during and after school improves their academic achievement, health benefit (Center for Disease Control and Prevention, 2010; Thompson, Singh, Ibarra-Castro, Woodward-Lopez, and Madsen, 2019). Also, classroom-based physical activity lessons have a positive impact on academic performance.

Some of the studies in the literature review also see facilities and equipment as a barrier to pupils' participation in physical education. When athletic facilities became more widely accessible, the pupils will be active and motivated to participate which reflect on the increased level of pupil's physical activity. Some of these problems include inadequate lesson instruction and time distribution, and a shortage of equipment, and a lack of resources. This study supports those findings and also goes beyond the existing literature's coverage by offering a comprehensive insight into the pupil's school-based physical education experiences of availability and participation in daily physical education lesson at Baku primary schools. Students should be given the capacity to expand their skills and talents, as well as be placed in environments that promote their professional growth. Students should be given the ability to learn about the influences that influence their physical potential and how to protect their health during their lives, as well as how physical exercise leads to emotional and physical well-being and planning. About the Azerbaijan curriculum (2.1.1.) under the purpose of primary education, the content standards of the general education which stated the rationale for the subject delivery by certified physical education teacher who has a full understanding of physical training as an important factor in health strengthening and protection, able to provide teaching and training to improve pupils' movement ability as well as using relevant tools 
and teaching style as a means of introducing the pupils to various areas of sports, mastering of personal hygiene rules and body strengthen as well as training of such qualities as a discipline, endurance, and independence.

As cited in Stead \& Nevill ( 2017), in a study conducted by Ahmed et al. (2007),in their report, children in grades 4 and 5 were given 50 minutes of extra physical exercise each week (i.e. 10 minutes per school day) at intervention schools. Despite the intervention party missing instructional lesson time, the findings of a regular academic exam after 16 months did not vary substantially between intervention and control schools (P0.05) (Ahmed et al.). This report also supported the claim of this study. (Ahmed et al.). further stated that Ten minutes of extra physical exercise a day may not have been long enough to provide academic benefits, but it is adequate to provide health benefits to the girls (WHO, 2010). Since it was intended to complement the current Canadian curriculum and was carried out by generalist teachers who obtained advanced training and research, the study is broadly applicable as a basic intervention. (SHAPE) report, which assigned 45-60 minutes of extra physical education each day. The study's results showed that daily physical exercise had health benefits. It is noteworthy that WHO 2017 and NASPE (2010) recommend letter categories and recess as regular components of school curricula. Physical Education is a part of the overall educational process and is required in elementary schools throughout the world (Pate et al., 1995; European Commission for Youth \& Sport, 2012). In Australia (Commonwealth of Australia, Department of Health and Aging, 2012), also in New Zealand (New Zealand Ministry of Health, Physical Activity Guidelines, 2010), nearly all elementary school children are required to participate in some form of physical activity (Eime et al., 2017).

\section{Conclusion}

The purpose of this study is to explore the impact of swapping subjects lesson on the availability of physical education (PE) and pupil's participation in physical education lesson daily at Baku primary schools. The study findings according to the result of the data analysis in summary indicated that physical education availability in Baku primary school is low according to which is "sometimes available" this is due to swapping of physical education lesson for other subjects considered important such as mathematics science, English to allow more instructional time for these subjects.

There is a significant correlation between swapping of physical education lesson availability of physical education at school and the pupil's participation. However, this study suggested more research should be conducted on the impact of physical education and physical activity on pupil's academic achievement. To also examine the association between pupil's participation and availability of facilities and equipment as well as the role of school directors and teachers on school-based physical education. If the children are not having direct access to physical activity and physical exercise at school, leading and healthy lifestyle now and in their adulthood could be jeopardized. 


\subsection{Suggestion}

The educational board and stakeholder could set up a committee to investigate this issue across the primary schools. Physical education should be made compulsory and an examination subject, this would help in decreasing the physical education time nor swapping the subject for other subjects considered examination or important subject. We need to put into consideration that physical education helps pupils comprehend how physical exercise could help them to develop a healthy lifestyle, gain a range of motor skills that help them to take part in a variety of physical activities and enjoy an active lifestyle.

\section{Conflict of Interest Statement}

The authors declare no conflicts of interests. There are no financial interests to report, and the co-author have seen and agreed with the contents of the work. We confirm that the manuscript submission is part of a master thesis project, it is original work, and it is not currently under review or consideration by another publisher.

\section{About the Author}

I have over 7 years of teaching experience and a bachelor's degree in Teaching English as a Second Language with a major in English Literature, and also a master's degree in Physical Education and a second master's degree in Educational Management. I am now pursuing a PhD in Educational Administration. Aside from being a K-12 teacher, I had a long soccer career that culminated with being named the University of Malaya's international students' sportsman of the year in 2014 and 2015. I am the founder of Educare, an organization dedicated to assisting students in study abroad programs, promoting educator's professional development and sports tours for young people. In addition, I volunteer as a research consultant with Mission89 and working group member of international safeguarding children in sports. I am currently working on my PhD project workplace professional development for teachers, leadership role of school directors on workplace professional development for in-service teachers, and student academic progress. these are variables to be address in the project. However, for future articles I would like to address some of these following issues such as K-12 teaching methods, physical education curriculum, pupils' motor learning and motor development, school environment and pupil's participation in physical activity, physical education, language teaching and learning research, schools and higher institution sports for children and youth development.

\section{References}

Anderson, Y., Wynter, L., Grant, C., reports, J. S.-S., \& 2017, undefined. (n.d.). Physical activity is low in obese New Zealand children and adolescents. Nature.Com. Retrieved from https://www.nature.com/articles/srep41822 
Bechter, B. E., Dimmock, J. A., \& Jackson, B. (2019). A cluster-randomized controlled trial to improve student experiences in physical education: Results of a studentcentered learning intervention with high school teachers. Psychology of Sport and Exercise, 45. doi:10.1016/j.psychsport.2019.101553

Behzadnia, B., Adachi, P. J. C., Deci, E. L., \& Mohammadzadeh, H. (2018). Associations between students' perceptions of physical education teachers' interpersonal styles and students' wellness, knowledge, performance, and intentions to persist at physical activity: A self-determination theory approach. Psychology of Sport and Exercise, 39, 10-19. doi:10.1016/j.psychsport.2018.07.003

Cheatom, O., Borden, L. M., Hawkey, K. R., Kuhl, M. W., Pinna, K. M., \& For. (2014). Parental Influence on Children's Physical Activity Motivation. Retrieved 29 March 2018, from https://reachmilitaryfamilies.umn.edu/sites/default/files/rdoc/Parental Influence on Children's Physical Activity Motivation.pdf

Constantinides, P., Montalvo, R., \& Silverman, S. (2013). Teaching processes in elementary physical education classes taught by specialists and nonspecialists. Teaching and Teacher Education, 36, 68-76. doi:10.1016/j.tate.2013.07.004

Eime, R. M., Harvey, J., Charity, M. J., Casey, M., Westerbeek, H., \& Payne, W. R. (2017). The relationship of sport participation to provision of sports facilities and socioeconomic status: a geographical analysis. Australian and New Zealand Journal of Public Health, 41(3), 248-255. doi:10.1111/1753-6405.12647

European Union Erasmus Program, E. (2014). How To Integrate Sport Into Curricular Activities. Retrieved from https://notonlyfairplay.pixelonline.org/files/toolkit/Toolkit_ENG_SHD02.pdf

Ha, A. S., Lonsdale, C., Lubans, D. R., \& Ng, J. Y. Y. (2017). Increasing students' physical activity during school physical education: Rationale and protocol for the SELF-FIT cluster randomized controlled trial. BMC Public Health, 18(1), 11. doi:10.1186/s12889-017-4553-8

Haerens, L., Kirk, D., Cardon, G., \& De Bourdeaudhuij, I. (2011). Toward the Development of a Pedagogical Model for Health-Based Physical Education. Quest (Vol. 63). Retrieved from

https://shapeamerica.tandfonline.com/doi/abs/10.1080/00336297.2011.10483684

Hills, A. P. (2007). Children, Obesity and Exercise. Children, Obesity and Exercise. doi:10.4324/9780203945971

Hills, A. P., Dengel, D. R., \& Lubans, D. R. (2015). Supporting Public Health Priorities: Recommendations for Physical Education and Physical Activity Promotion in Schools. Progress in Cardiovascular Diseases, 57(4), 368-374. doi:10.1016/j.pcad.2014.09.010

Jenkinson, K. A., \& Benson, A. C. (2010). Barriers to providing physical education and physical activity in Victorian state secondary schools. Australian Journal of Teacher Education, 35(8), 1-17. doi:10.14221/ajte.2010v35n8.1 
Kearsley, G., \& Schneiderman, B. (2006). Engagement theory: A framework for technology-based learning and teaching (1999). Originally at Http://Home. Sprynet. Com/ Gkearsley/Engage. Htm.

Korthagen, F. (2017). Inconvenient truths about teacher learning: towards professional development 3.0. Teachers and Teaching: Theory and Practice, 23(4), 387-405. doi:10.1080/13540602.2016.1211523

Lewis, K. (2014a). Pupils' and teachers' experiences of school-based physical education: A qualitative study. BMJ Open, 4(9). doi:10.1136/bmjopen-2014-005277

Lewis, K. (2014b). Pupils' and teachers' experiences of school-based physical education: A qualitative study. BMJ Open, 4(9). doi:10.1136/bmjopen-2014-005277

Lunenberg, M., \& Korthagen, F. (2009). Experience, theory, and practical wisdom in teaching and teacher education. Teachers and Teaching: Theory and Practice, 15(2), 225-240. doi:10.1080/13540600902875316

Mackenzie, S. H., Son, J. S., \& Eitel, K. (2018). Using outdoor adventure to enhance intrinsic motivation and engagement in science and physical activity: An exploratory study. Journal of Outdoor Recreation and Tourism, 21, 76-86. doi:10.1016/j.jort.2018.01.008

Ministry of Education. (2005). Daily physical activity in schools: Grades 1 to 3. Retrieved from http://www.edu.gov.on.ca.

Oluwaseyi Olubunmi Sodiya1, \& Syed Kamaruzaman Bin Syed Ali2. (2017). Result of Mental Imagery and Demonstration Intervention on Primary Four Pupiles Acquisition of Soccer Dribbling Skills. International Journal of Science and Research (IJSR) ISSN: 2319-7064 Index Copernicus Value (2016): 79.57 I Impact Factor (2017): 7.296, 7(8), 1466-1477. doi:10.21275/ART2019800

Packham, A., \& Street, B. (2019). The effects of physical education on student fitness, achievement, and behavior. Economics of Education Review, 72, 1-18. doi:10.1016/j.econedurev.2019.04.003

Pakhalchuk, N. O., \& Holyuk, O. A. (2018). Problems of physical activity in vocational training of future teachers. Physical Education of Students, 22(1), 45. doi:10.15561/20755279.2018.0107

Prins, R. G., Van Empelen, P., Te Velde, S. J., Timperio, A., Van Lenthe, F. J., Tak, N. I., ... Oenema, A. (2010). Availability of sports facilities as moderator of the intentionsports participation relationship among adolescents. Health Education Research, 25(3), 489-497. doi:10.1093/her/cyq024

Quitério, A. L. D. (2013). School physical education: The effectiveness of health-related interventions and recommendations for health-promotion practice. Health Education Journal, 72(6), 716-732. doi:10.1177/0017896912460934

Rasberry, C. N., Lee, S. M., Robin, L., Laris, B. A., Russell, L. A., Coyle, K. K., \& Nihiser, A. J. (2011, June 1). The association between school-based physical activity, including physical education, and academic performance: A systematic review of the literature. Preventive Medicine. doi:10.1016/j.ypmed.2011.01.027 
Republic, C. of M. of the A. (2006). General Education Concept (National Curriculum) In Azerbaijan Republic. Retrieved from https://edu.gov.az/upload/file/milli_kurikulum-eng.pdf

SHAPE. (2014). National standards and Grade-level outcomes for K-12 physical education. Retrieved 31 October 2019, from Visit www.shapeamerica.org/standards/pe

Smedegaard, S., Christiansen, L. B., Lund-Cramer, P., Bredahl, T., \& Skovgaard, T. (2016). Improving the well-being of children and youths: a randomized multicomponent, school-based, physical activity intervention. BMC Public Health, 16(1), 1-11. doi:10.1186/s12889-016-3794-2

Stead, R., \& Nevill, M. (2017). The Impact of Physical Education and Sport on Education Outcomes: a Review of Literature, (September), 1-45. Retrieved from http://www.icsspe.org/system/files/Stead and Neville - The Impact of Physical Education and Sport on Education Outcomes_0.pdf

Syrmpas, I., Digelidis, N., Watt, A., \& Vicars, M. (2017). Physical education teachers' experiences and beliefs of production and reproduction teaching approaches. Teaching and Teacher Education, 66, 184-194. doi:10.1016/j.tate.2017.04.013

Thompson, H. R., Singh, B. K., Ibarra-Castro, A., Woodward-Lopez, G., \& Madsen, K. A. (2019). Access to credentialed elementary physical education teachers in California and students' cardiorespiratory fitness. Preventive Medicine, 121, 62-67. doi:10.1016/j.ypmed.2019.01.021 

be applied to their work. Under the terms of this license, no permission is required from the author(s) or publisher for members of the community to copy, distribute, transmit or adapt the article content, providing a proper, prominent and unambiguous attribution to the authors in a manner that makes clear that the materials are being reused under permission of a Creative Commons License. Views, opinions and conclusions expressed in this research article are views, opinions and conclusions of the author(s). Open Access Publishing Group and European Journal of Physical Education and Sport Science shall not be responsible or answerable for any loss, damage or liability caused in relation to/arising out of conflict of interests, copyright violations and inappropriate or inaccurate use of any kind content related or integrated on the research work. All the published works are meeting the Open Access Publishing requirements and can be freely accessed, shared, modified, distributed and used in educational, commercial and non-commercial purposes under a Creative Commons attribution 4.0 International License (CC BY 4.0). 